\title{
Municipal solid waste composition: Sampling methodology, statistical analyses, and case study evaluation
}

Edjabou, Vincent Maklawe Essonanawe; Jensen, Morten Bang; Götze, Ramona; Pivnenko, Kostyantyn; Petersen, Claus; Scheutz, Charlotte; Astrup, Thomas Fruergaard

Published in:

Waste Management

Publication date:

2015

Document Version

Peer reviewed version

Link back to DTU Orbit

Citation (APA):

Edjabou, V. M. E., Jensen, M. B., Götze, R., Pivnenko, K., Petersen, C., Scheutz, C., \& Astrup, T. F. (2015). Municipal solid waste composition: Sampling methodology, statistical analyses, and case study evaluation. Waste Management, 36, 12-23. http://10.1016/j.wasman.2014.11.009

\section{General rights}

Copyright and moral rights for the publications made accessible in the public portal are retained by the authors and/or other copyright owners and it is a condition of accessing publications that users recognise and abide by the legal requirements associated with these rights.

- Users may download and print one copy of any publication from the public portal for the purpose of private study or research.

- You may not further distribute the material or use it for any profit-making activity or commercial gain

- You may freely distribute the URL identifying the publication in the public portal 
12 nd revision of manuscript.

2

3 Municipal Solid Waste Composition:

$4 \quad$ Sampling methodology, statistical

5 analyses, and case study evaluation

6

$7 \quad$ Maklawe Essonanawe Edjabou ${ }^{1 *}$, Morten Bang Jensen ${ }^{1}$,

8 Ramona Götze ${ }^{1}$, Kostyantyn Pivnenko ${ }^{1}$, Claus Petersen ${ }^{2}$,

$9 \quad$ Charlotte Scheutz ${ }^{1}$, Thomas Fruergaard Astrup ${ }^{1}$

10

1) Department of Environmental Engineering, Technical University of Denmark, 2800 Kgs. Lyngby, Denmark

2) Econet AS, Omøgade 8, 2.sal, 2100 Copenhagen, Denmark

*) Corresponding author: vine@env.dtu.dk; 


\section{Abstract}

22 Sound waste management and optimisation of resource

23

24 recovery require reliable data on solid waste generation and composition. In the absence of standardised and commonly accepted waste characterization methodologies, various approaches have been reported in literature. This limits both comparability and applicability of the results. In this study, a waste sampling and sorting methodology for efficient and statistically robust characterisation of solid waste was introduced. The methodology was applied to residual waste collected from 1442 households distributed among 10 individual sub-areas in three Danish municipalities (both single and multi-family house areas). In total 17 tonnes of waste were sorted into 10-50 waste fractions, organised according to a three-level (tiered approach) facilitating comparison of the waste data between individual sub-areas with different fractionation (waste from one municipality was sorted at "Level III", e.g. detailed, while the two others were sorted only at "Level I"). The results showed that residual household waste mainly contained food waste $(42 \pm 5 \%$, mass per wet basis) and miscellaneous combustibles ( $18 \pm 3 \%$, mass per wet basis). The residual household waste generation rate in the study areas was 3-4 kg per person per week. Statistical analyses revealed that the waste composition was independent of variations in the waste generation rate. Both, waste composition and waste 
46 generation rates were statistically similar for each of the three

47 municipalities. While the waste generation rates were similar

48 for each of the two housing types (single-family and multi-

49 family house areas), the individual percentage composition of

50 food waste, paper, and glass was significantly different between

51 the housing types. This indicates that housing type is a critical

52 stratification parameter. Separating food leftovers from food

53 packaging during manual sorting of the sampled waste did not

54 have significant influence on the proportions of food waste and

55 packaging materials, indicating that this step may not be

56 required.

\section{Key words:}

58 Residual household waste

59 Waste generation rate

60 Waste fractions

61 Statistical analysis

62 Waste sampling

63 Waste composition 


\section{Introduction}

66 Accurate and reliable data on waste composition are crucial

67 both for planning and environmental assessment of waste management as well as for improvement of resource recovery in society. To develop the waste system and improve technologies, detailed data for the material characteristics of

71 the waste involved are needed. Characterization of waste

72 material composition typically consists of three phases: first

73 sampling of the waste itself, then sorting the waste into the

74 desired number of material fractions (e.g. paper, plastic,

75 organics, combustibles, etc.), and finally handling,

76 interpretation and application of the obtained data. The

77 sampling and sorting activities themselves are critical for

78 obtaining appropriate waste composition data. The absence of

79 international standards for solid waste characterization has led

80 to a variety of sampling and sorting approaches, making a

81 comparison of results between studies challenging (Dahlén and

82 Lagerkvist, 2008). Due to the high heterogeneity of solid

83 waste, the influence of local conditions (e.g. source-

84 segregation systems, local sorting guides, collection equipment

85 and systems), and the variability of sampling methodologies

86 generally limits the applicability of waste compositional data

87 in situations outside the original context.

88 The quality of waste composition data are highly affected

89 by the sampling procedure (Petersen et al., 2004). Solid waste 
sampling may often involve direct sampling, either at the source (e.g. household) (WRAP, 2009) or from a vehicle load (Steel et al., 1999). Vehicle load sampling is often carried out by sampling the waste received at waste transfer stations

94 (Wagland et al., 2012), waste treatment facilities, e.g. waste 95 incinerators (Petersen, 2005), and landfill sites (Sharma and 96 McBean, 2009; Chang and Davila, 2008). While logistic

97 efforts can be reduced by sampling at the point of unloading of

98 waste collection vehicles, a main drawback of this approach

99 may be that the sampled waste cannot be accurately attributed 100 to the geographical areas and/or household types generating 101 the waste (Dahlén et al., 2009). This limits the applicability of 102 the obtained composition data. On the other hand, collecting 103 waste directly from individual households and/or from a 104 specific area with a certain household type, allow the waste 105 data to be associated with the specific area (Dahlén et al., 106 2009). Additionally, as most modern waste collection trucks 107 use a compaction mechanism (Nilsson, 2010), waste fractions 108 sampled from such vehicles have been affected by mechanical 109 stress and blending, which leads to considerable difficulties in 110 distinguishing individual material fractions during manual 111 sorting (European Commission, 2004). Owing to the

112 mechanical stress and the blending processes from collection

113 trucks, cross-contamination between individual fractions may

114 occur, leading to further inaccuracies that can neither be 
115 measured nor corrected afterwards.

116 To ensure uniform coverage of the geographical area

117 under study, stratification sampling is often applied. This

118 involves dividing the study area into non-overlapping sub-

119 areas with similar characteristics (Dahlén and Lagerkvist,

120 2008; Sharma and McBean, 2007; European Commission,

121 2004).

122 In order to reduce the volume (amount) of waste to be

123 sorted, the waste sampled from each sub-area is usually coned

124 and quartered before sorting into individual waste material

125 fractions (Choi et al., 2008; Martinho et al., 2008). Although

126 this reduces labour intensity, the approach has shown to

127 generate poorly representative samples (Gerlach et al., 2002).

128 Because of the heterogeneity of residual household waste

129 (RHW), the material in a waste pile (or cone) is unevenly

130 distributed (Klee, 1993). Instead, sampling from elongated flat

131 piles and from falling streams at conveyor belts is

132 recommended to generate more representative samples (De la

133 Cruz and Barlaz, 2010, Petersen et al., 2005). While elongated

134 flat piles can be used on most waste materials, sampling from

135 falling streams at conveyor belts may potentially induce

136 additional mechanical stress if not appropriately applied.

137 However, only few studies have applied these mass reduction

138 principles for solid waste sampling prior to the manual sorting

139 in fractions. The waste sampled from a specific sub-area could 
140 also be split into a desired or calculated number of sub-samples

141 (European Commission, 2004, Nordtest, 1995). This method

142 can provide mean and standard deviation for each waste

143 fraction, and may be argued as cost-effective (Sharma and

144 McBean, 2007). However, the main drawback is the splitting,

145 which can introduce a bias. Additionally, the obtained standard

146 deviations are highly associated with the number of samples

147 and the size (mass or volume) of the samples, which vary

148 considerably across literature (Dahlén and Lagerkvist, 2008).

149 In order to avoid any bias from mass reduction, sorting all the

150 collected waste from an individual sub-area would be

151 necessary (Petersen et al., 2004).

152 In addition to the influence from waste sampling, also the

153 subsequent sorting procedures can influence the results for

154 household waste composition. The overall material fraction

155 composition is directly related to the sorting principles applied

156 for dividing waste materials into individual fractions, e.g. to

157 which extent is food packaging and food materials separated,

158 how are composite materials handled, and how detailed

159 material fractions are included in the study? The influence of

160 food waste sorting procedures has been investigated by

161 Lebersorger and Schneider (2011). While the influence of food

162 packaging on food waste in this particular case was shown to

163 be insignificant, the influence of food packaging on other

164 material fractions in the waste (e.g. packaging material) has 
not been examined.

Inconsistencies among existing solid waste

characterisation studies, e.g. definitions of waste fractions,

may cause confusion and limit comparability of waste

composition data between studies (Dahlén and Lagerkvist, 2008). While Riber et al. (2009) published a detailed waste

composition for household waste, including 48 waste material

fractions, more transparent and flexible nomenclature for the

individual waste material fractions is needed to allow full

comparability between studies with varying numbers of

material fractions and sorting objectives. Such classification

principles exist, but only for certain waste types and often

developed for other purposes: e.g. classification of plastics

based on resin type (Avella et al., 2001), the European Union's

directive on Waste Electrical and Electronic Equipment

(WEEE) (European Commission, 2003) and grouping of

Household Hazardous Waste (HHW) (Slack et al., 2004).

The overall aim of the paper was to provide a consistent

framework for municipal solid waste characterisation activities

and thereby support the establishment of transparent waste

composition datasets. The specific objectives were to: i)

introduce a waste sampling and sorting methodology involving

a tiered list of waste fractions (e.g. a sequential subdivision of

fractions at three levels), ii) apply this methodology in a

concrete sampling campaign characterising RHW from 10 
individual sub-areas located in three different municipalities, iii) evaluate the methodology based on statistical analysis of

192 the obtained waste datasets for the 10 sub-areas, focusing on

193 the influence of stratification criteria and sorting procedures

194 (e.g. the influence of sorting of food waste packaging on other

195 packaging materials), and iv) identify potential trends among

196 sub-areas in source-segregation efficiencies.

\section{Materials and methods}

\section{$198 \quad 2.1$ Definitions}

199 RHW refers to the remaining mixed waste after source segregation of recyclables and other materials, such as HHW,

201 WEEE, gardening and bulky waste. Bulky waste refers to

202 waste such as furniture, refrigerators, television sets, and

203 household machines (Christensen et al., 2010). Source-

204 segregated material fractions found in the residual household

205 waste are considered as miss-sorted waste fractions. Housing

206 type consists of single-family and multi-family house. Here

207 single-family house corresponds to households with their own

208 residual waste bin, while multi-family house corresponds to

209 households sharing residual waste bins, e.g. common

210 containers in apartment buildings. Food packaging is

211 packaging containing food remains or scraps. "Packed food"

212 waste represents food items inside packaging while "unpacked

213 food" waste is food discarded without packaging. Within this

214 paper, the terms "fraction" and "component" was used 
215 interchangeably. The data are presented as mean and standard

216 deviation (Mean \pm SD) unless otherwise indicated.

$217 \quad 2.2$ Study area

218 The sampling campaign covered residual waste collected from

219 households in three Danish municipalities: Aabenraa,

220 Haderslev and Sønderborg. These municipalities have the same

221 waste management system including the same source

222 segregation scheme. They introduced a waste sorting system

223 using a two-compartment wheeled waste bin for separate

224 collection of recyclable materials from single-family house

225 areas (Dansk Affald, 2013). One compartment was used for

226 collection of mixed metal, plastic, and glass; the other

227 compartment for mixed paper, board, and plastic foil. However,

228 in multi-family house areas, a Molok system and joint full

229 service collection points (joint wheeled container) were used

230 for the collection of RHW and source-sorted materials for

231 recyclables. The waste bins had volumes between 60 to 360

232 litres in the single-family house area and between 400 to 1000

233 litres in the multi-family house area.

234 Collection frequencies for the residual waste were every

235 two weeks in single-family house areas and every week in

236 multi-family house areas. Garden waste, HHW, WEEE and

237 bulky waste from single and multi-family house areas could be

238 disposed of, either at recycling stations or collected from the

239 premises on demand. However, food waste was not separately 
240 collected and was disposed of in the RHW bin. This study

241 focused not on the source-segregated materials (bulky waste,

242 garden waste, and other source-segregated materials), but rather

243 on the characterisation of the residual waste consisting of a

244 mixed range of materials of high heterogeneity.

\section{$245 \quad 2.3$ Waste sampling procedure}

246 The three municipalities were subdivided into sub-areas

247 distinguished by housing type. RHW was sampled directly

248 from households in each of the 10 sub-areas; three sub-areas

249 were from Aabenraa, three from Sønderborg, and four from

250 Haderslev. As such, the sampling campaign focused on the

251 overall waste generation from the individual sub-areas and the

252 associated housing types, rather than the specific waste

253 generated in each household.

254 To avoid changes of the normal waste collection

255 patterns within the areas (see section 2.2) potentially leading to

256 changes in household waste disposal behaviour, the waste was

257 collected following the existing residual waste collection

258 schedules.

259 A single RHW collection route was selected in each

260 sub-area by the municipal authorities responsible for the solid

261 waste management. The distribution of households along the

262 selected routes was representative for each sub-area with

263 respect to the volume of RHW bins and the size of the

264 households. The number of selected households in each sub- 
area was between 100 and 200, as recommended by Nordtest

266 (1995). representativeness and number of households), the number of selected households were computed and reported in Table 1, which also shows the amount of waste collected and sorted

271 from each sub-area. In total, 426 households in Aabenraa, 389

272 households in Sønderborg and 627 households in Haderslev

273 were selected. Overall, 779 households were distributed in four

274 multi-family house areas, and 663 households in six single-

275 family house areas.

277 from multi-family house areas and 11 tonnes from single-

278 family house areas (overall 17 tonnes). The waste was sampled

279 during spring 2013. Any effects from seasonal variations on

280 waste composition and generation rates were not investigated

281 in the study.

\section{Table 1 about here}

\section{$283 \quad 2.4$ Sorting procedure}

284 In order to avoid errors from waste splitting, the entire waste

285 sampled from each sub-area was sorted as a "batch" and the

286 waste from the 10 sub-areas was treated each as a "single

287 sample", resulting in 10 individual samples from the three

288 municipalities. This means that as a result of the sorting

289 campaign, waste data (waste composition and waste generation) 
for 10 individual sub-areas were obtained.

For this reason, the waste was collected separately from

292 each sub-area without compacting (e.g. the waste was not

293 collected by a compaction vehicle). The waste was then

294 transported to a sorting facility, where it was unloaded on a

295 tarpaulin, and filled in paper sacks for weighing and temporary

296 storage. The paper sacks were labelled with ID numbers. Each

297 paper sack was weighed to obtain the "dry mass" before filling

298 in the waste. Thereafter, the filled paper sacks were weighed

299 before and after all sorting activities to quantify mass losses

300 during sorting and storage. The mass loss was calculated as the

301 difference in net mass of waste before and after a process. The

302 errors due to contamination during sorting process and storage,

303 e.g. the migration of moisture from food waste to other

304 components (paper, board, plastic, etc.) and paper sacks, and

305 evaporation was negligible (see Supplementary material D for

306 mass losses). The average mass loss was $1.7 \%$, and thus below

$3073 \%$ (Lebersorger and Schneider, 2011). No adjustments of the

308 waste data from errors due to mass losses were applied in this

309 study.

310 Figure 1 illustrates the waste sorting procedure and the steps

311 applied. A tiered approach for material fraction sorting was

312 developed as illustrated by Levels I to III in Table 2, to allow

313 comparison between datasets with different needs for sorting

314 and data aggregation. For example, one study may focus on 
315 detailed fractionation of food waste (e.g. addressing avoidable

316 and non-avoidable food), while another study may only wish to

317 characterize food waste by a few overall fractions (e.g.

318 vegetable and animal derived food waste). Categorizing the

319 fractions in levels (e.g. Levels I to III) would thereby still allow

320 comparison between such two studies, at an overall level. In the

321 context of the sub-areas, all collected waste from each sub-area

322 was sorted separately. This was done according to Level I in

323 Table 2, corresponding to 10 material fractions. To provide

324 further details, waste from one municipality (Aabenraa) was

325 selected for more detailed sorting according to Level II \& III.

326 The waste from Haderslev and Sønderborg was sorted only at

327 Level I. As such, the datasets from these three municipalities

328 represent examples of sorting campaigns carried out at different

329 levels of complexity; nevertheless, the tiered approach allows

330 comparison between the datasets at Level I.

Food packaging containing remaining food was

332 separated as an extra fraction and subsequently sorted

333 separately into the individual material fractions as shown in

334 Table 2. Food waste including beverage was easily removed

335 from the packaging. However, in some cases tools were used

336 e.g. to open containers, or packaging was compressed as much

337 as possible to remove food waste e.g. from tube packaging.

All waste fractions from Aabenraa,including food

339 packaging containing remaining food leftovers were 
340 subsequently sorted according to the three levels in Table 2

341 (Level I, II and III). For instance, plastic waste was sorted by

342 reading the resin identification label on the plastic. Unspecified

343 plastic represented plastic where no resin identification label

344 was present. Metal fractions were sorted into ferrous and non-

345 ferrous using a magnet. As the contents of "special waste"

346 including WEEE and HHW were very low, this fraction was

347 sorted only to Level II.

348 The waste sampled from each sub-area was sorted

349 under the same conditions, by a professional team, within a

350 week from the sampling day. This sorting time may minimize

351 any physical changes of the samples as recommended by

352 European Commission (2004).

\section{Figure 1 about here}

$354 \quad 2.5$ Waste fraction nomenclature

355 The waste fraction nomenclature was mainly adapted from

356 Riber et al. (2009) and other literature (Steel et al., 1999, Dixon

357 and Langer, 2006), and the Danish National Waste register

358 (Danish EPA, 2014). Naming conventions for the individual

359 material fractions may be affected by local traditions and may

360 be ambiguously defined. Special care was taken here to ensure

361 consistent naming of fractions and avoid potential misleading

362 names. The tiered fraction list is shown in Table 2 and consists

363 of 10 fractions at Level I, 36 fractions at Level II, and 56

364 fractions at Level III. This nomenclature allowed transparent 
365 classification while still facilitating flexible grouping of waste

366 fractions and comparison between the individual areas. For

367 example, we used food waste and gardening waste instead of

368 organic waste, which by definition includes more than food

369 waste and gardening waste. Here, food waste comprises food

370 and beverage products that are intended for human

371 consumption, including edible material (e.g. fruit and

372 vegetables, and meat) and inedible material (e.g. bones from

373 meat, eggshells, and peels) (WRAP, 2009). Paper was divided

374 into advertisements, books \& booklets, magazines \& journals,

375 newspapers, office paper, phonebooks and miscellaneous paper.

376 Miscellaneous paper was then further subdivided into

377 envelopes, kraft paper, other paper, receipts, self-adhesives,

378 tissue paper, and wrapping paper. Plastic waste was subdivided

379 according to resin type (PET, HDPE, PVC, LDPE, PP, PS,

380 Other resins) (Avella et al., 2001) and unidentified plastic

381 resins for plastic with no resin identification. Special waste was

382 categorised as batteries (single batteries and non-device specific

383 batteries), WEEE and HHW. WEEE and HHW were further

384 split into components defined by the EU directive on WEEE

385 and HHW.

Table 2 about here

$387 \quad 2.6$ Statistical analysis

388 The waste generation rate (WGR) and composition of the

389 residual waste were analysed by the Kruskal-Wallis test and 
the permutation test (Johnson, 2005) to identify significant

391 differences among the three municipalities and between the

392 two housing types. Furthermore, the Kolmogorov-Smirnov test

393 (Johnson, 2005) was applied to identify cases when the

394 proportion of at least one fraction in the overall composition

395 was significantly different between housing types or among

396 municipalities. Based on Spearman's correlation test (Johnson,

397 2005) a correlation matrix between the WGR and percentages

398 of individual waste fractions was determined (Crawley, 2007).

399 Correlations between the WGR and individual waste fractions

400 were used to determine whether variations in WGR also

401 influenced the waste composition, while correlations between

402 waste fractions were used to identify potential trends in the

403 households' efficiency in source segregating of recyclables

404 (e.g. based on leftover recyclables in the residual waste). The

405 test of the correlation for significance addressed whether the

406 correlation's coefficients were statistically significant or

407 significantly different from zero (Crawley, 2007).

$408 \quad$ Waste composition data were reported and discussed

409 based on the relative distribution of fractions in percentages of

410 wet mass (as opposed to the quantity of wet mass of individual

411 waste fraction) to ensure scale invariance and enable

412 comparison of waste composition from different areas

413 (Buccianti and Pawlowsky-Glahn, 2011). Additionally,

414 percentage composition data remove the effects from WGR 
415 (since in the study area, the WGR varies according to sub-

416 areas), which could otherwise lead to "false" correlations

417 (Egozcue and Pawlowsky-Glahn, 2011). This approach allows

418 comparison of different waste composition data. However,

419 waste composition data in percentages are "closed datasets"

420 because the proportions of individual fractions are positive and

421 add up to a constant of 100 (Filzmoser and Hron, 2008). As

422 such, these data require special treatment or transformation

423 prior to statistical analyses (Aitchison, 1994; Filzmoser and

424 Hron, 2008; Reimann et al., 2008). Here, log-transformation

425 was applied since "the log-transformation is in the majority of

426 cases advantageous for analysis of environmental data, which

427 are characterised by the existence of data outliers and most

428 often right-skewed data distribution” (Reimann et al., 2008).

429 Data analysis was carried out with the statistical

430 software R. Data for three municipalities (Sønderborg,

431 Haderslev, and Aabenraa), two housing types (single and

432 multi-family), and two sorting procedures (with and without

433 including food packaging in the food waste component) were

434 investigated. The influence of including food packaging in the

435 food waste fraction was modelled by comparing two waste

436 composition datasets: 1) data from the sorting campaign where

437 food packaging was separated from food waste and added to

438 the relevant material fraction, and 2) a "calculated" dataset

439 where the mass of food packaging was added to the food waste 
fraction.

442 obtained for each sub-area, aggregated waste compositions

443 (corresponding to Level I) were computed for each

444 municipality and each housing type. These waste compositions

445 accounted for the relative distribution of housing types and

446 number of households among sub-areas (Statistics Denmark,

447 2013).

$448 \quad 3$ Results and discussion

449 3.1 Comparison with previous Danish composition 450 data

451 The detailed composition of the RHW from Aabenraa is shown

452 in Table 3 for Level I \& II and in Table 4 mainly for Level III.

453 Food waste (41-45\%) was dominating the waste composition,

454 and it consisted of vegetable food waste (31-37\%) and animal-

455 derived food waste (8-10\%). Plastic film (7-10\%) and human

456 hygiene waste (7-11\%) were also important RHW fractions.

457 The proportion of miss-sorted material fractions was estimated

458 to be $26 \%$ of the total RHW, of which 20 to $22 \%$ were

459 recyclable material fractions (see Table 3). These results were

460 comparable with those found in a previous Danish study, which

461 found values of $41 \%$ food waste, $31 \%$ vegetable food waste

462 and 10\% animal-derived food waste (Riber et al., 2009).

463 Although, the households in the previous study did not source

464 segregate board, metal and plastic, the percentages of board

465 (7\%), plastic (9\%), metal (3\%) glass (3\%), inert (4\%) and 
466 special waste (1\%) were also similar in the two studies. The

467 main differences between these studies were related to the

468 detailed composition of paper and combustible waste. Despite

469 the fact that paper (advertisement, books, magazines and

470 journals, newspapers, office paper and phonebooks) was source-

471 segregated in both studies, in our study paper contributed with

$4727-9 \%$ of the total waste (4\% was tissue paper, see Table 4 ),

473 while Riber et al. (2009) reported a paper content of $16 \%$

474 (mainly advertisement, newsprints and magazines). Although

475 variations in source-segregation schemes may potentially

476 explain these differences, other factors such as sorting guides,

477 income levels, demographics and developments in general

478 consumption patterns may also affect data.

Table 3 about here

\subsection{Comparison between municipalities}

481 RHW compositions for the Level I fractions for each sub-area

482 are shown in Figure 2. For all three areas, food and

483 miscellaneous combustible waste were the largest components

484 of the RHW. Paper, board and plastic constituted individually

485 between 5 and $15 \%$ of the total RHW. The proportion of special

486 waste was less than $1 \%$ and was the smallest fraction of the total

487 RHW.

488 The waste generation rates for RHW were expressed in

$489 \mathrm{~kg}$ per person per week and estimated at 3.4 \pm 0.2 in Aabenraa,

$4903.5 \pm 0.2$ in Haderslev, and 3.5 \pm 1.4 in Sønderborg. Waste 
491 composition between municipalities showed minor differences.

492 The highest percentage of food $(44 \pm 3 \%)$ and plastic $(15 \pm 1 \%)$,

493 and the lowest percentage of miscellaneous combustible waste

$494(15 \pm 4 \%)$ were found in Sønderborg. The highest miscellaneous

495 combustible waste $(19 \pm 4 \%)$ was in Haderslev, while the

496 highest inert $(4 \pm 4 \%)$ was in Aabenraa.

497 The composition and the WGRs for each municipality

498 are compared in Table 5 based on the Kruskal-Wallis test. No

499 examples of significant differences in either WGR or waste

500 composition could be observed for the three municipalities.

501 This may indicate that in areas with identical source-

502 segregation systems and similar sorting guides for households,

503 data for individual sub-areas (municipalities) may statistically

504 represent the sub-areas. While this conclusion is only relevant

505 for the specific material composition (Level I) and the socio-

506 economic and geographical context, the results also suggest

507 that the composition data may be applicable to other similar

508 areas (e.g. similar housing types, geography, etc.) in Denmark.

509 In contrast to this, a review of waste composition analyses in

510 Poland (Boer et al., 2010) showed high variability in waste

511 composition and WGR between individual cities. According to

512 Boer et al., 2010, these differences could be attributed to

513 different waste characterisation methods used in each city, and

514 to differences in waste management systems between these

515 cities. Therefore, a consistent waste characterisation 
methodology was recommended to facilitate any comparison of

517 solid waste composition among these cities.

Table 6 provides an overview of waste compositions

519 corresponding to Level I for a range of studies in literature.

520 Most of these studies found that food waste was the

521 predominant RHW fraction, although the percentage of food

522 waste varied considerably among studies. For instance, food

523 waste accounted for $19 \%$ of the total RHW in Canada (Sharma

524 and McBean, 2007), 25\% in Wales (Burnley et al., 2007), 30\%

525 in Sweden (Bernstad et al., 2012) and $56 \%$ in Spain (Montejo

526 et al., 2011). On the other hand, RHW contained only $12 \%$ of

527 food waste after paper (33\%) and wood (24\%) in South Korea

528 (Choi et al., 2008). Similarly, in Italy food waste was only $12 \%$

529 of RHW, which was predominantly made of paper (39\%) and

530 plastic (27\%) (AMSA, 2008). These differences may be related

531 to: i) socio-economic and geographical factors (consumption

532 patterns, income, climate,) (Khan and Burney, 1989), ii) waste

533 management system (source-segregation, waste collection

534 systems), iii) local regulation (Johnstone, 2004), and iv) waste

535 characterisation methodology (type of waste characterised,

536 terminology as well as waste sampling and characterisation

537 methodologies) (Beigl et al., 2008). The comparison between

538 composition data clearly illustrate the difficulties related to

539 comparison and applicability of aggregated data. 
$541 \quad 3.3$ Correlations between waste generation rates and 542 waste fractions

543 The correlation test identified significant relationships between

544 WGR and composition of RHW as well as among the

545 proportion of individual waste fractions. The correlation test

546 among the proportion of individual waste fractions was carried

547 out to evaluate whether available free space in the RHW bin

548 could influence source-segregation behaviour of the

549 households. The resulting Spearman correlation matrix is

550 shown in Table 7, where both correlation coefficients and their

551 significance levels are provided.

552 From Table 7, WGR appeared to be negatively

553 correlated with food, gardening waste, plastic, metal and inert

554 waste fractions, and positively correlated with miscellaneous

555 combustibles, board, glass and special waste. However, none of

556 these correlations were statistically significant. This indicated

557 that the percentages of individual waste fractions varied

558 independently of the overall WGR within the study areas. It

559 also suggested that distribution of waste fractions in the RHW

560 might not be estimated based on variations of the overall waste

561 generation rate.

562 The proportion of glass was negatively and highly

563 significantly correlated with the proportion of food waste ( $\mathrm{r}=-$

564 0.81). Likewise, a high negative correlation between

565 miscellaneous combustible waste and gardening waste was 
566 observed $(\mathrm{r}=-0.82)$. This suggests that when proportions of

567 food waste and miscellaneous combustible waste decreases, the

568 proportions of gardening and glass waste (potentially miss-

569 sorted recyclable glass) increase correspondingly. These results

570 suggest that sorting of glass and gardening waste could be

571 affected by the amounts of food waste and other miscellaneous

572 waste generated by the household.

$573 \quad 3.4$ Influence of housing type on composition

574 The weighted composition and WGR for each housing type are

575 presented in Table 8 together with the associated probability

576 values ( $p$-values $<0.05$ indicate significant difference). RHW

577 from single-family house areas contained significantly higher

578 fractions of food waste than multi-family house areas. On the

579 other hand, RHW from multi-family house areas contained a

580 higher share of paper and glass waste than single-family house

581 areas. However, the $\mathrm{p}$-value $(\mathrm{p}=0.123)$ of the Kolmogorov-

582 Smirnov test for the overall difference in waste composition

583 was not significant.

584 In Austria, Lebersorger and Schneider (2011) found a

585 statistically significant difference between housing types;

586 however, RHW from multi-family house areas had significantly

587 higher percentage of food waste than RHW from single-family

588 house areas. In Poland for example, Boer et al. (2010) showed

589 that the overall household waste composition depended on the

590 type of housing, because of the differences in heating systems 
591

592

593

594

595

596

597

598

599

600

601

602

603

604

605

606

607

608

609

610

611

612

613

of the households.

Figure 2 about here

Table 5 about here

\subsection{Influence of sorting practices on composition}

Food packaging comprised about $20 \%$ of "packed food", $7 \%$ of the total food waste and nearly $3 \%$ of the total RHW as shown in Figure 3a. Total food waste consisted of $66 \%$ of "unpacked food" waste (30\% of the total RHW), $27 \%$ of "packed food" waste (12\% of the total RHW) and $7 \%$ of food packaging.

\section{Table 6 about here}

The composition of food packaging is shown in Figure

3b. Food packaging consisted of plastic (50\%), paper and board (25\%), metal (10\%) and glass (13\%). These results were comparable to literature data reporting food packaging to represent about $8 \%$ of avoidable food waste (Lebersorger and Schneider, 2011), and food packaging consisting of $40 \%$ of plastic, $25 \%$ of paper, $22 \%$ of glass and $13 \%$ of metal (Dennison et al., 1996).

Figure 3 about here

Table 9 presents the composition of RHW based on waste sorting and the probability values from the permutation test. For this case study, no statistically significant effect on the percentage of food waste and the overall RHW composition 
614 could be observed from sorting practices for food waste (e.g.

615 whether or not packaging was included in the food fraction).

616 This may be explained by the fact that the food packagings

617 were predominently made of plastic only contributing with low

618 mass compared to the food waste and other fractions.

619 Consistently, Lebersorger and Schneider (2011) found that the

620 "packed food" waste had a relative high mass compared to its

621 packagings.

Table 7 about here

Table 8 about here

6243.6 Implications for waste characterisation and 625 applicability of composition data

626 The tiered approach for fractionation of solid waste samples

627 offered sufficient flexibility to organise waste composition

628 data, both at an overall level (e.g. Level I for comparison

629 between municipalities) but also to report more detailed data

630 (for Aabenraa at Level III). The suggested waste fraction list

631 accounted for current European legislation governing the

632 classification of WEEE and HHW, and key characteristics for

633 plastic and metal waste. This type of categorisation enables, to

634 a certain extent, comparison among future and existing studies,

635 and among studies with different focus and need for details.

636 This may potentially increase the applicability of the obtained

637 waste composition data. 
High data quality is facilitated since the methodology

640 follows appropriate sampling procedures proposed by Dahlén

641 and Lagerkvist (2008) to minimize sampling errors as described

642 by Pitard (1993): i) heterogeneity fluctuation errors were

643 addressed by stratification, ii) fundamental sampling errors due

644 to the heterogeneity of RHW were reduced by sampling at

645 household level from a recommended sample size (100-200

646 households) to obtain representative results (Nordtest, 2005);

647 iii) grouping and segregation errors, and increment delimitation

648 errors were reduced by avoiding sample splitting and instead

649 sorting the entire waste quantity sampled; and iv) increment

650 extraction errors due to contamination and losses of waste

651 materials were minimized by avoiding compacting the sampled

652 waste during transportation, and sieving before sorting.

The case study showed that detailed waste composition

654 of any miss-placed WEEE and HHW required larger sample

655 sizes than was included here (or alternatively that the

656 household source segregation of these waste types was

657 sufficiently efficient to allow only small amounts in the RHW).

658 As both WEEE and HHW should be collected separately, this

659 observation only refers to miss-placed items in the RHW.

660 General characterization of WEEE and HHW should be carried

661 out based on samples specifically from these flows (this was

662 however outside the scope of the study). The manual sorting of 
663 plastic waste into resin type was time consuming as resin

664 identification was needed for each individual plastic item;

665 however, the detailed compositional data provided by this

666 effort offer considerably more information that simple

667 categories such as "recyclable plastic" or "clean plastic". This

668 information is indispensable for national or regional waste

669 statistics as basis for estimating the potential of recycling of

670 postconsumer plastics and environmental sound management of

671 non-recyclable plastics. Furthermore, the plastic

672 characterisation based on resin type is needed as input for

673 detailed life cycle assessment and material flow analyses of

674 plastic waste management.

675 Separation of food packaging from food leftovers,

676 however, was found unnecessary because this division into sub-

677 fractions did not significantly influence the waste composition;

678 this clearly reduces time invested in the sorting campaign, but

679 also improves the hygienic conditions during the sorting

680 process. As the statistical analyses indicated no statistical

681 difference in waste composition between municipalities, waste

682 composition data obtained from one municipality could be

683 applied to other municipalities in the study area (provided the

684 municipalities share source-segregation schemes). This may be

685 used as a basis for reducing the sampling area (and thereby

686 overall waste quantities) in a sampling campaign. However, the

687 statistical differences observed between housing types in 
688

689

690

691

692

693

694 for a specific area (with consistent socio-economic and

695

696

697

698

699

700

701

702

703

704

705

706

707

708

709 fractions. This tiered fraction list was applied on a case study

710

711 within three municipalities. Sub-areas in two municipalities

712 were sorted only at the first level (overall waste fractions), 
713 while waste from one municipality was sorted to the third level

714 (e.g. two sub-levels below the overall waste fractions). The

715 obtained waste data (generation rates and composition) for the

716 individual sub-areas were compared for identification of

717 significant differences between the areas. Based on the

718 statistical analysis, it was found that while overall waste

719 composition and generation rates were not significantly

720 different between the three municipalities, the waste

721 composition from single-family and multi-family houses were

722 different. This indicates that while waste composition data may

723 be transferred from one municipality to another (provided the

724 source-segregation schemes are sufficiently similar),

725 differences in housing types cannot be ignored. As opposed to a

726 more "linear" waste fraction catalogue, the three-level fraction

727 list applied in this study allowed a systematic comparison

728 across the datasets of different complexity.

729 The results of the sorting analysis indicated that food packaging

730 did not significantly influence the overall composition of the

731 waste as well as the proportions of food waste, plastics, board,

732 glass and metal. Specific separation of food packaging from

733 food leftovers during sorting was therefore not critical for

734 determination of the waste composition. 
737 The authors acknowledge the Danish Strategic Research

738 Council for financing this study via the IRMAR project. The

739 municipalities of Aabenraa, Haderslev, and Sønderborg are also

740 acknowledged for partly supporting the waste sampling

741 campaign.

742

743 Supplementary material

744 Supplementary material contains background information about

745 the data used for calculations and detailed data from the waste

746 characterisation campaign.

747 
References

Aitchison, J., 1994. A Concise Guide to Compositional Data Analysis. Lect. Notes-Monograph Ser. 24, 73-81.

AMSA, 2008. 2, Dichiarazione Ambientale Termovalorizzatore Silla.

Arena, U., Mastellone, M.., Perugini, F., 2003. The environmental performance of alternative solid waste management options: a life cycle assessment study. Chemical Engeering Journal. 96, 207-222.

Avella, M., Bonadies, E., Martuscelli, E., Rimedio, R., 2001. European current standardization for plastic packaging recoverable through composting and biodegradation. Polym. Test.

Banar, M., Cokaygil, Z., Ozkan, A., 2009. Life cycle assessment of solid waste management options for Eskisehir, Turkey. Waste Management 29, 54-62.

Beigl, P., Lebersorger, S., Salhofer, S., 2008. Modelling municipal solid waste generation: a review. Waste Management. 28, 200 214.

Bernstad, A., la Cour Jansen, J., Aspegren, H., 2012. Local strategies for efficient management of solid household waste--the fullscale Augustenborg experiment. Waste Management \& Research 30, 200-12.

Boer, E. Den, Jedrczak, A., Kowalski, Z., Kulczycka, J., Szpadt, R., 2010. A review of municipal solid waste composition and quantities in Poland. Waste Management 30, 369-77.

Buccianti, A., Pawlowsky-Glahn, V., 2011. Compositional Data Analysis, Compositional Data Analysis: Theory and Applications. John Wiley \& Sons, Ltd, Chichester, UK.

Burnley, S., 2007. A review of municipal solid waste composition in the United Kingdom. Waste Management 27, 1274-1285

Burnley, S.J., Ellis, J.C., Flowerdew, R., Poll, a. J., Prosser, H., 2007. Assessing the composition of municipal solid waste in Wales. Resources, Conservation and Recycling 49, 264-283.

Chang, N.-B., Davila, E., 2008. Municipal solid waste characterizations and management strategies for the Lower Rio Grande Valley, Texas. Waste Management 28, 776-794

Choi, K.-I., Lee, S.-H., Lee, D.-H., Osako, M., 2008. Fundamental characteristics of input waste of small MSW incinerators in Korea. Waste Management 28, 2293-2300. 
Christensen, T.H., Fruergaard, T., Matsufuji, Y., 2010. Residential Waste, in: Christensen, T.H. (Ed.), Solid Waste Technology \& Management, Volume 1 \& 2. John Wiley \& Sons, Ltd, Chichester, UK

Crawley, M.J., 2007. The R book, John Wiley \& Sons Ltd. Wiley.

Dahlén, L., Berg, H., Lagerkvist, A., Berg, P.E.O., 2009. Inconsistent pathways of household waste. Waste Management 29, 17981806

Dahlén, L., Lagerkvist, A., 2008. Methods for household waste composition studies. Waste Management 28, 1100-1112.

Danish EPA, 2014. ISAG [WWW Document]. URL http://mst.dk/virksomhed-myndighed/affald/tal-foraffald/registrering-og-indberetning/isag/ (accessed 9.10.14).

Dansk Affald, 2013. Sorting DuoFlex-waste containers [WWW Document]. URL http://www.danskaffald.dk/index.php/da/projekt-sagavelkommen/affalds-sortering/duoflex-affaldet\#.U5b-o_mSzz8 (accessed 6.10.14).

De la Cruz, F.B., Barlaz, M. a, 2010. Estimation of waste component-specific landfill decay rates using laboratory-scale decomposition data. Environmental Science \& Technology 44, 4722-8.

Dennison, G.J., Dodda, V.A., Whelanb, B., 1996. A socio-economic based survey of household waste characteristics in the city of Dublin, Ireland . I . Waste composition 3449.

Dixon, N., Langer, U., 2006. Development of a MSW classification system for the evaluation of mechanical properties. Waste Management 26, 220-232.

Egozcue, J. J. and Pawlowsky-Glahn, V. ,2011. Basic Concepts and Procedures, in Compositional Data Analysis: Theory and Applications (eds V. Pawlowsky-Glahn and A. Buccianti), John Wiley \& Sons, Ltd, Chichester, UK. doi: 10.1002/9781119976462.chapter2

European Commission, 2004. Methodology for the Analysis of Solid Waste (SWA-tool). User Version 43, 1-57

European Commission, 2003. DIRECTIVE 2002/96/EC OF THE EUROPEAN PARLIAMENT AND OF THE COUNCIL of 27 January 2003 on waste electrical and electronic equipment (WEEE) [WWW Document]. URL http://www.bis.gov.uk/files/file29931.pdf (accessed 2.6.14). 
827 Filzmoser, P., Hron, K., 2008. Correlation Analysis for

828 Compositional Data. Mathematical Geosciences. 41, 905-919.

829 Gerlach, R.W., Dobb, D.E., Raab, G. a., Nocerino, J.M., 2002. Gy

830 sampling theory in environmental studies. 1. Assessing soil

831 splitting protocols. Journal of Chemometrics 16, 321-328

832 Horttanainen, M., Teirasvuo, N., Kapustina, V., Hupponen, M., Luoranen, M., 2013. The composition, heating value and renewable share of the energy content of mixed municipal solid waste in Finland. Waste Management 33, 2680-2686

Johnson, R.A., 2005. Miller \& Freund's Probability and statistics for engineers, Seventh ed. ed. Pearson Prentice-Hall.

Johnstone, N., 2004. Generation of household solid waste in OECD countries: An empirical analysis using macroeconomic data. Land Economics 80, $529-538$.

841

842

843

844

845

846

847

848

849

850

851

852

853

854

855

856

857

858

859

860

861

862

863

864

865

866

867

Khan, M.Z.A., Burney, F.A., 1989. Forecasting solid waste composition - An important consideration in resource recovery and recycling. Resources, Conservation and Recycling $3,1-17$.

Klee, A., 1993. New approaches to estimation of solid waste quantity and composition. Journal of Environmental Engineering 119, $248-261$.

Lebersorger, S., Schneider, F., 2011. Discussion on the methodology for determining food waste in household waste composition studies. Waste Management 31, 1924-33.

Martinho M.G.M., M. da G., Silveira, A. I., Fernandes Duarte Branco, E. M., 2008. Report: New guidelines for characterization of municipal solid waste: the Portuguese case. Waste Management \& Research 26, 484-490.

Moh, Y.C., Abd Manaf, L., 2014. Overview of household solid waste recycling policy status and challenges in Malaysia. Resources Conservation Recycling. 82, 50-61

Montejo, C., Costa, C., Ramos, P., Márquez, M.D.C., 2011. Analysis and comparison of municipal solid waste and reject fraction as fuels for incineration plants. Applied Thermal Engineering 31, 2135-2140.

Nilsson, P., 2010. Waste Collection: Equipment and Vehicles, in: Christensen, T.H. (Ed.), Solid Waste Technology \& Management, Volume $1 \& 2$. John Wiley \& Sons, Ltd, Chichester, UK.

Nordtest, 1995. Municipal solid waste: Sampling and characterisation ( No. NT ENVIR 001), Nordtest Method. Espoo, Finland. 
Petersen, C.M., 2005. Quality control of waste to incineration - waste composition analysis in Lidkoping, Sweden. Waste Management \& Research 23, 527-533.

Petersen, L., Dahl, C.K., Esbensen, K.H., 2004. Representative mass reduction in sampling - a critical survey of techniques and hardware. Chemometrics and Intelligent Laboratory Systems $74,95-114$.

Petersen, L., Minkkinen, P., Esbensen, K.H., 2005. Representative sampling for reliable data analysis: Theory of Sampling. Chemometrics and Intelligent Laboratory Systems 77, 261-277.

Pitard, F.F., 1993. Pierre Gy's Sampling Theory and Sampling Practice, Second Edition: Heterogeneity, Sampling Correctness, and Statistical Process Control. CRC Press.

Reimann, C., Filzmoser, P., Garrett, R.G., Dutter, R., 2008. Statistical Data Analysis Explained, Statistical Data Analysis Explained: Applied Environmental Statistics With R. John Wiley \& Sons, Ltd, Chichester, UK.

Riber, C., Petersen, C., Christensen, T.H., 2009. Chemical composition of material fractions in Danish household waste. Waste Management 29, 1251-1257.

Sharma, M., McBean, E., 2007. A methodology for solid waste characterization based on diminishing marginal returns. Waste Management 27, 337-44.

Sharma, M., McBean, E., 2009. Strategy for use of alternative waste sort sizes for characterizing solid waste composition. Waste Management \& Research 27, 38-45.

Slack, R., Gronow, J., Voulvoulis, N., 2004. Hazardous Components of Household Waste. Critical Review in Environmental Science. Technologie.

Statistics Denmark, 2013. Housing [WWW Document]. URL http://www.dst.dk/en/Statistik/emner/boligforhold.aspx (accessed 12.21.13).

Steel, E.A., Hickox, W., Moulton-patterson, L., 1999. Statewide Waste Characterization Study Results and Final Report.

Wagland, S.T., Veltre, F., Longhurst, P.J., 2012. Development of an image-based analysis method to determine the physical composition of a mixed waste material. Waste Management 32, 245-248.

WRAP (Waste \& Resources Action Programme), 2009. Household Food and Drink Waste in the UK, October. 
910 Tables

911 Table 1: Overview of the sub-areas, number of household per

912 stratum and amount of waste sampled and analysed

\begin{tabular}{llcl}
\hline Municipalities & Housing type & Number of household per sampling unit & Amount analysed (kg wet \\
\hline \multirow{3}{*}{ Aabenraa } & Single- family & 100 & 1,500 \\
& Multi-family & 106 & 600 \\
& Multi-family & 220 & 1,100 \\
Haderslev & Single- family & 94 & 2,200 \\
& Single- family & 100 & 1,700 \\
& Single- family & 100 & 1,400 \\
Sonderborg & Multi-family & 333 & 3,300 \\
& Single- family & 105 & 2,200 \\
Total & Single- family & 164 & 2,200 \\
& Multi-family & 120 & 600 \\
\end{tabular}

913

914

915

916

917

918

919

920

921

922

923

924

925

926

927

928

929

930 
Table 2: The waste fractions list showing three different levels (Level I, Level II, and Level III)

\begin{tabular}{|c|c|c|}
\hline Level I & Level II & Level III \\
\hline 1-Food waste & 1.1 Vegetable food waste; 1.2 Animal-derived food waste & - \\
\hline 2-Gardening waste & $\begin{array}{l}\text { 2.1 Dead animal and animal excrements (excluding cat litter); } \\
\text { 2.2 Garden waste }\end{array}$ & $\begin{array}{l}\text { 2.1.1 Dead animals; } 2.1 .2 \text { Animal excrement bags from animal excrement } \\
\text { 2.2.1 Humid soil; } 2.2 .2 \text { Plant material; } 2.2 .3 \text { Woody plant material; 2.2.4 Animal } \\
\text { straw. }\end{array}$ \\
\hline 3-Paper & $\begin{array}{l}\text { 3.1 Advertisements; } 3.2 \text { Books \& booklets; } 3.3 \text { Magazines \& Journals; } 3.4 \\
\text { Newspapers; } 3.5 \text { Office paper; } 3.6 \text { Phonebooks; } \\
\text { 3.7 Miscellaneous paper. }\end{array}$ & $\begin{array}{l}\text { 3.7.1 Envelopes; 3.7.2 Kraft paper; 3.7.3 Other paper; } 3.7 .4 \text { Receipts; 3.7.5 Self- } \\
\text { Adhesives; 3.7.6 Tissue paper; 3.7.7 Wrapping paper }\end{array}$ \\
\hline 4-Board & $\begin{array}{l}\text { 4.1 Corrugated boxes; } \\
\text { 4.2 Folding boxes; } 4.3 \text { Cartons/plates/cups; } \\
4.4 \text { Miscellaneous board. }\end{array}$ & $\begin{array}{l}\text { 4.4.1 Beverage cartons; 4.4.2 Paper plates \& cups; } \\
\text { 4.4.3 Cards \& labels; 4.4.4 Egg boxes \& alike; 4.4.5 Other board; 4.4.6 Tubes. }\end{array}$ \\
\hline 5-Plastic & $\begin{array}{l}\text { 5.1 Packaging plastic; } \\
\text { 5.2 Non-packaging plastic; } \\
\text { 5.3 Plastic film. }\end{array}$ & 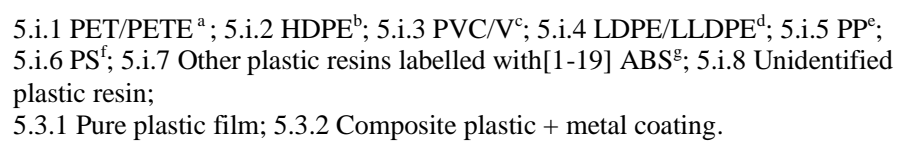 \\
\hline 6-Metal & $\begin{array}{l}\text { 6.1 Metal packaging containers; } \\
6.2 \text { Non-packaging metals; } 6.3 \text { Aluminium wrapping foil }\end{array}$ & 6.i.1 Ferrous; 6.i.2 Non-ferrous (with i=1\&2). \\
\hline 7-Glass & $\begin{array}{l}\text { 7.1 Packaging container glass; } \\
\text { 7.2 Table and kitchen ware glass; } 7.3 \text { Other/special glass. }\end{array}$ & 7.i.1 Clear; 7.i.2 Brown; 7.i.3 Green. \\
\hline 8-Miscellaneous combustibles & $\begin{array}{l}\text { 8.1 Composites, human hygiene waste (Diapers, tampons, condoms, etc.); } 8.2 \\
\text { textiles, leather and rubber; } 8.3 \text { Vacuum cleaner bags; } 8.4 \text { Untreated wood; } \\
8.5 \text { Other combustible waste. }\end{array}$ & $\begin{array}{l}\text { 8.1.1 Diapers; } 8.1 .2 \text { Tampons; } 8.1 .1 \text { Condoms; } \\
\text { 8.2.1 Textiles; 8.2.2 Leather; 8.2.3 Rubber; }\end{array}$ \\
\hline 9-Inert & $\begin{array}{l}\text { 9.1 Ashes from households; } 9.2 \text { Cat litter; } 9.3 \text { Ceramics, gravel; } 9.4 \text { Stones } \\
\text { and sand; } 9.5 \text { Household constructions \& demolition waste. }\end{array}$ & - \\
\hline 10-Special waste & $\begin{array}{l}\text { 10.1 Single Batteries/ non-device specific Batteries; } 10.2 \text { WEEE; } 10.3 \text { Other } \\
\text { household hazardous waste. }\end{array}$ & $\begin{array}{l}\text { 10.3.1Large household appliances; 10.3.2 Small household appliances; } 10.3 .3 \text { IT } \\
\text { and telecommunication equipment; 10.3.4 Consumer equipment and photovoltaic } \\
\text { panels; } 10.3 .5 \text { Lighting equipment; 10.3.6 Electrical and electronic tool (no large- } \\
\text { scale stationary tools), 10.3.7 Toys, leisure and sports equipment; } 10.3 .8 \text { Medical } \\
\text { devices (except implanted and infected products); 10.3.9 Monitoring and control } \\
\text { instruments; 10.3.10 Automatic dispensers. }\end{array}$ \\
\hline
\end{tabular}

${ }^{a}$ Polyethylene terephthalate $;{ }^{b}$ density polyethylene; ${ }^{c}$ Polyvinyl-chloride; ${ }^{d}$ Low density polyethylene; ${ }^{e}$ : Polypropylene; ${ }^{f}$ : Polystyrene; ${ }^{g}:$ Acrylonitrile/butadiene/styrene Numbering of waste fractions: $n$ - fractions included in Level I, n.n fractions included in Level II, n.n.n fractions included in Level III; 
1 Table 3: Waste composition (\% mass per wet basis) of RWH

2 from Aabenraa-Level I \& II

\begin{tabular}{|c|c|c|}
\hline Fractions (Level II) & $\mathbf{S F}^{\mathbf{d}}\left(\% \mathrm{w} / \mathrm{w}^{\mathrm{a}}\right)$ & $\mathbf{M F}\left(\% \mathrm{w} / \mathrm{w}^{\mathrm{a}}\right)$ \\
\hline \multicolumn{3}{|l|}{ Food waste } \\
\hline Vegetable food waste & 36.5 & 31.3 \\
\hline Animal-derived food waste & 8.1 & 9.5 \\
\hline \multicolumn{3}{|l|}{ Gardening waste } \\
\hline Dead animal and animal excrements (exclude cat litter) & 0.5 & 0.3 \\
\hline Garden waste etc. & 4.8 & 3.1 \\
\hline \multicolumn{3}{|l|}{ Paper } \\
\hline Advertisements $^{\mathrm{a}}$ & 0.9 & 2.8 \\
\hline Books \& booklets ${ }^{\mathrm{a}}$ & 0.1 & 0.4 \\
\hline Magazines \& Journals ${ }^{\mathrm{a}}$ & 0.3 & 0.5 \\
\hline Newspapers $^{\mathrm{a}}$ & 0.5 & 0.8 \\
\hline Office paper ${ }^{\mathrm{a}}$ & 0.7 & 0.4 \\
\hline Phonebooks $^{\mathrm{a}}$ & 0.0 & 0.0 \\
\hline Miscellaneous paper & 4.6 & 4.2 \\
\hline \multicolumn{3}{|l|}{ Board } \\
\hline Corrugated boxes ${ }^{\mathrm{a}}$ & 0.4 & 0.7 \\
\hline Folding boxes ${ }^{\mathrm{a}}$ & 1.5 & 2.0 \\
\hline Beverage cartons & 4.6 & 3.3 \\
\hline Miscellaneous board & 0.8 & 0.6 \\
\hline \multicolumn{3}{|l|}{ Plastic } \\
\hline Non-packaging plastic & 0.5 & 0.9 \\
\hline Packaging plastic ${ }^{\mathrm{a}}$ & 5.1 & 4.5 \\
\hline Plastic film & 9.8 & 6.6 \\
\hline \multicolumn{3}{|l|}{ Metal } \\
\hline Metal packaging containers ${ }^{\mathrm{a}}$ & 1.3 & 1.9 \\
\hline Aluminium wrapping foil & 0.0 & 0.0 \\
\hline Non-packaging metals & 0.6 & 0.7 \\
\hline \multicolumn{3}{|l|}{ Glass } \\
\hline Packaging container glass ${ }^{\mathrm{a}}$ & 1.8 & 2.2 \\
\hline Table and kitchen ware glass ${ }^{\mathrm{a}}$ & 0.2 & 0.0 \\
\hline Other/special glass ${ }^{\mathrm{a}}$ & 0.1 & 0.1 \\
\hline \multicolumn{3}{|l|}{ Miscellaneous combustible } \\
\hline Human hygiene waste (Diapers, tampons, condoms, etc.) & 7.3 & 10.8 \\
\hline Wood untreated & 0.6 & 0.3 \\
\hline Textiles, leather and rubber & 2.8 & 2.4 \\
\hline Vacuum cleaner bags & 1.1 & 0.4 \\
\hline Other combustible waste & 2.4 & 5.6 \\
\hline \multicolumn{3}{|l|}{ Inert } \\
\hline Ashes from households & 0.0 & 0.0 \\
\hline Cat litter & 0.8 & 2.3 \\
\hline Ceramics & 0.2 & 0.3 \\
\hline Gravel, stones and sand & 0.3 & 0.6 \\
\hline Household construction \& demolition waste ${ }^{\mathrm{b}}$ & 0.1 & 0.1 \\
\hline \multicolumn{3}{|l|}{ Special waste ${ }^{\mathbf{b}}$} \\
\hline Single Batteries/ non device specific Batteries & 0,1 & 0.1 \\
\hline WEEE & 0,3 & 0,1 \\
\hline Other household hazardous waste & 0,3 & 0.2 \\
\hline Total & 100 & 100 \\
\hline
\end{tabular}

3 Miss-sorted recyclable material fractions; ${ }^{b}$ Miss-sorted other material fractions; ${ }^{c}$

4 Composition of single-family as\% wet weight;

$5{ }^{d}$ Composition of multi-family as (\% mass per wet basis) 
6 Table 4: Detailed waste composition (\% mass per wet basis) of

7 RWH from Aabenraa focusing on Level III

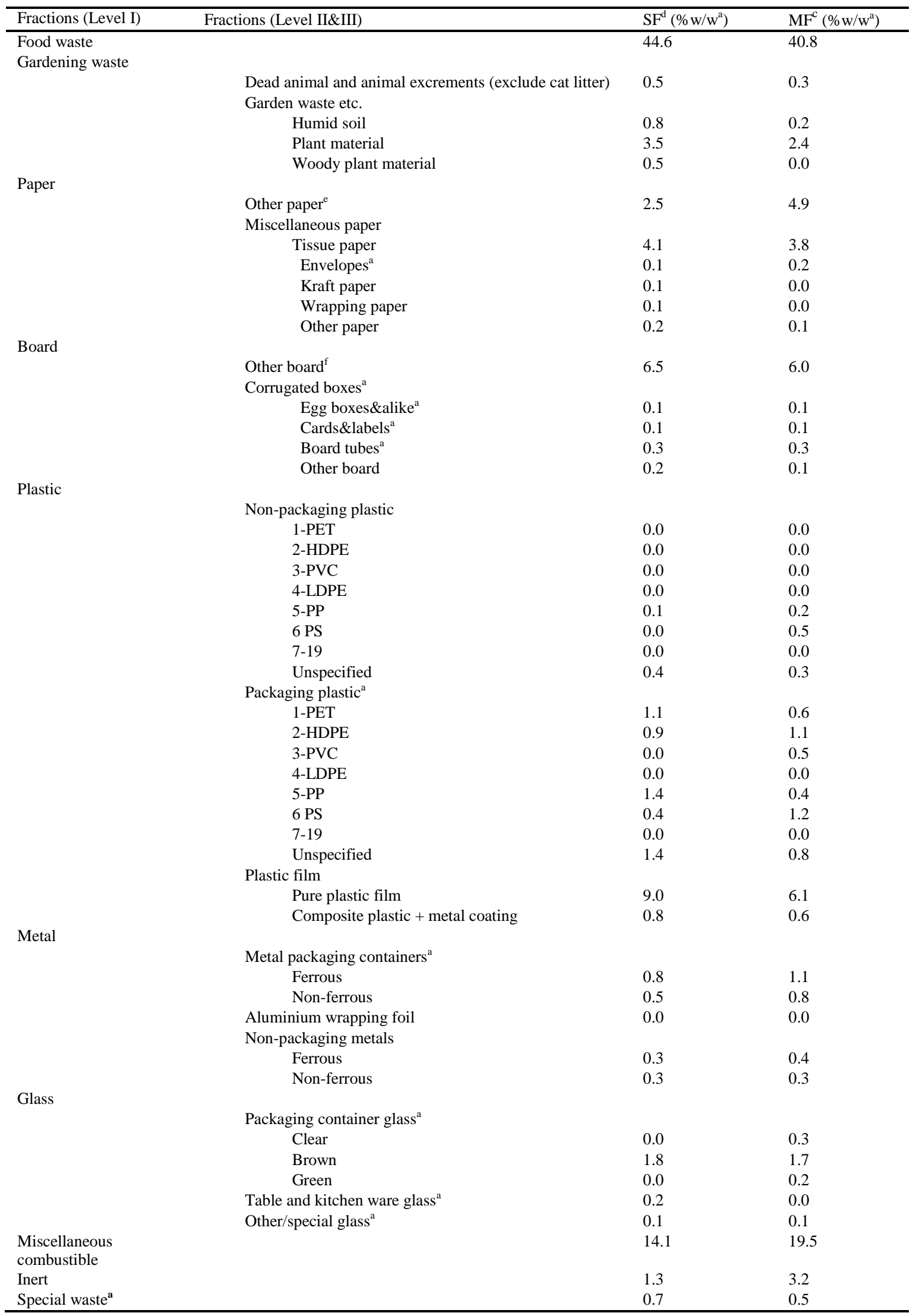


Total $\frac{1}{a}$ Miss-sorted recyclable material fractions: ${ }^{b}$ Miss-sorted other material fractions, ${ }^{c}$

Miss-sorted recyclable material fractions; Miss-sorted other material fractions,

10 family houses areas as (\% mass per wet basis); ${ }^{e}$ Advertisements, books \& booklet,

11 magazines \& journals, newspaper, office paper, phonebook; ${ }^{f}$ Corrugated boxes, folding boxes,

12 beverage cartons

Table 5: Composition (\% mass per wet basis) of RHW as

15 function of municipality and associated probability values from

16 the Kruskal-Wallis test. The last row shows the WGR

17 (kg/per/week)

\begin{tabular}{lllll}
\hline Fractions (Level1) & Aabenraa $\left(\% \mathrm{w} / \mathrm{w}^{\mathrm{a}}\right)$ & Haderslev $\left(\% \mathrm{w} / \mathrm{w}^{\mathrm{a}}\right)$ & Sønderborg $\left(\% \mathrm{w} / \mathrm{w}^{\mathrm{a}}\right)$ & $\mathrm{p}$-value \\
\hline Food waste & $42.8 \pm 5.2$ & $41.7 \pm 6.4$ & $43.8 \pm 3$ & 0.999 \\
Gardening waste & $3.8 \pm 1.0$ & $2.6 \pm 1.0$ & $5 \pm 1.7$ & 0.565 \\
Paper & $8.3 \pm 1.0$ & $8.9 \pm 2.4$ & $7.6 \pm 1.2$ & 0.993 \\
Board & $7.1 \pm 1.0$ & $8.1 \pm 1.6$ & $7.1 \pm 0$ & 0.387 \\
Plastic & $12.6 \pm 1.2$ & $11.7 \pm 0.5$ & $14.8 \pm 0.6$ & 0.457 \\
Metal & $2.3 \pm 0.6$ & $2.2 \pm 0$ & $2.0 \pm 0.6$ & 0.984 \\
Glass & $1.7 \pm 0.6$ & $2.3 \pm 1.3$ & $2.1 \pm 2$ & 0.387 \\
Miscellaneous combustible & $17.6 \pm 3.5$ & $19 \pm 3.6$ & $15.2 \pm 3.5$ & 0.812 \\
Inert & $3.5 \pm 3.5$ & $2.5 \pm 1.5$ & $1.7 \pm 1.5$ & 0.731 \\
Special waste & $0.4 \pm 0.6$ & $1.0 \pm 0.8$ & $0.7 \pm 0.6$ & 0.314 \\
WGR (kg per person per week) & $3.4 \pm 0.2$ & $4.3 \pm 1.5$ & $3.5 \pm 1.4$ & 0.689 \\
\hline
\end{tabular}

18 Data are presented as Mean \pm Standard deviation; Significant level: $p<0.05 ; a$ :

19 (mass per wet basis)

20

21 
22 Table 6: Review of household solid waste composition (\%

23 mass per wet basis)

\begin{tabular}{cccccccccccc}
\hline Country & $\begin{array}{l}\text { Organic/ } \\
\text { Food } \\
\text { waste }\end{array}$ & $\begin{array}{l}\text { Gardening } \\
\text { waste }\end{array}$ & $\begin{array}{l}\text { Paper } \\
\text { board }\end{array}$ & Glass & Metal & Plastic & $\begin{array}{l}\text { Miscellaneous } \\
\text { combustible }\end{array}$ & Inert & $\begin{array}{l}\text { Special } \\
\text { waste }\end{array}$ & Fines & Total \\
\hline $\mathrm{DK}^{\mathrm{a}}$ & 42.2 & 3.5 & 15.8 & 12.6 & 2.3 & 2.1 & 17.6 & 3.3 & 0.7 & - & 100 \\
$\mathrm{DK}^{\mathrm{b}}$ & 41 & 4.1 & 23.2 & 9.2 & 3.3 & 2.9 & 12.2 & 3.5 & 0.7 & - & 100 \\
$\mathrm{ES}^{\mathrm{c}}$ & 56.2 & 1.84 & 19.04 & 3.3 & 2.96 & 10.67 & 4.927 & 0.69 & 0.12 & 100 \\
$\mathrm{FI}^{\mathrm{d}}$ & 23.9 & - & 15.3 & 2.5 & 3.8 & 21.4 & 19.9 & 10.4 & 1.7 & - & 100 \\
$\mathrm{IT}^{\mathrm{e}}$ & 30.1 & 3.9 & 23.2 & 5.7 & 3.3 & 10.8 & 4.5 & 1.3 & 8.7 & 9.4 & 100 \\
$\mathrm{IT}^{\mathrm{f}}$ & 12.6 & - & 39.2 & 5.9 & 2.4 & 27.6 & 14.2 & & & 100 \\
$\mathrm{PL}^{\mathrm{g}}$ & 23.7 & & 14.1 & 9.2 & 2.1 & 10.8 & 10.6 & 4.5 & 1 & 24.1 & 100 \\
$\mathrm{SE}^{\mathrm{h}}$ & 33 & 9.4 & 24 & 2.4 & 2.2 & 11.7 & 9.6 & 7 & 0.6 & - & 100 \\
$\mathrm{UK}^{\mathrm{i}}$ & 32.8 & - & 21.5 & 10.6 & 4.8 & 6.9 & 9.3 & 12.5 & 1.5 & - & 100 \\
$\mathrm{UK}^{\mathrm{j}}$ & 20.2 & - & 33.2 & 9.3 & 7.3 & 10.2 & 12 & 1.8 & & 6.8 & 100 \\
$\mathrm{TR}^{\mathrm{k}}$ & 67 & 0 & 10.1 & 2.5 & 1.3 & 5.6 & 9.7 & 3.9 & - & - & 100 \\
$\mathrm{KR}^{1}$ & 12 & - & 33 & - & - & 17 & 32 & 6 & - & - & 100 \\
$\mathrm{CA}^{\mathrm{m}}$ & 18.8 & 5.6 & 32.3 & 3.1 & 3.4 & 13.1 & 14.0 & 2.9 & 5.9 & 100 \\
$\mathrm{MA}^{\mathrm{n}}$ & 44.8 & & 16 & 3 & 3.3 & 15 & 9.5 & 8.4 & - & - & 100 \\
\hline
\end{tabular}

$24{ }^{a}$ Current study

$25{ }^{b}$ Denmark (Riber et al., 2009)

$26 \quad$. Spain (Montejo et al.,2011)

$27 \quad$. Finland (Horttanainen et al., 2013)

28 e. Italy (Arena et al., 2003)

29 . Italy (AMSA, 2008)

$30 \quad$ S. Poland (Boer et al., 2010)

31 h. Sweden (Petersen, 2005)

$32 \quad{ }^{i}$. United Kingdom (Burnley, 2007)

33 j. United Kingdom (Wales) (Burnley et al., 2007)

$34 \quad{ }^{k}$. Turkey (Banar et al., 2009)

35 '. Korea (Choi et al., 2008)

$36 \quad{ }^{m}$. Canada (Sharma and McBean, 2007)

$37 n^{n}$. Malaysia (Moh and Abd Manaf, 2014) 
Table 7: Correlation matrix from Spearman's correlation test (r: range $=-1.00-+1.00)$

\begin{tabular}{|c|c|c|c|c|c|c|c|c|c|c|c|}
\hline & Food & $\begin{array}{l}\text { Gardening } \\
\text { waste }\end{array}$ & Paper & Board & Plastic & Metal & Glass & $\begin{array}{l}\text { M. } \\
\text { combustible }^{\mathrm{a}}\end{array}$ & Inert & $\begin{array}{l}\text { Special } \\
\text { waste }\end{array}$ & $\mathrm{WGR}^{\mathrm{b}}$ \\
\hline Food & 1 & & & & & & *** & & & & \\
\hline Paper & -0.44 & -0.21 & 1 & & & & & & & & \\
\hline Metal & -0.54 & -0.35 & 0.07 & 0.49 & 0.03 & 1 & $*$ & & & & \\
\hline Glass & -0.81 & -0.15 & 0.43 & 0.67 & 0.04 & 0.7 & 1 & & & + & \\
\hline $\begin{array}{l}\text { M. } \\
\text { combustible }^{\mathrm{a}}\end{array}$ & -0.24 & -0.82 & 0.36 & -0.07 & -0.58 & 0.09 & 0.15 & 1 & & & + \\
\hline $\mathrm{WGR}^{\mathrm{b}}$ & -0.36 & -0.28 & 0.38 & 0.31 & -0.21 & -0.26 & 0.24 & 0.64 & -0.49 & 0.33 & 1 \\
\hline
\end{tabular}

(**) high significance probability between 0.001 and $0.01 ;\left(^{*}\right)$ medium significance,

43 probability between 0.01 and $0.05 ;(+)$ weak significance-probability between 0.05

44 and 0.10 ; () no significance-probability higher than 0.1

$45{ }^{a}$ Miscellaneous combustible; ${ }^{b}$ waste generation rate ( $k g$ RHW per person per week)

47 Table 8: Composition (\% mass per wet basis) of RHW as

48 function of housing type and associated probability values from

49 the permutation test

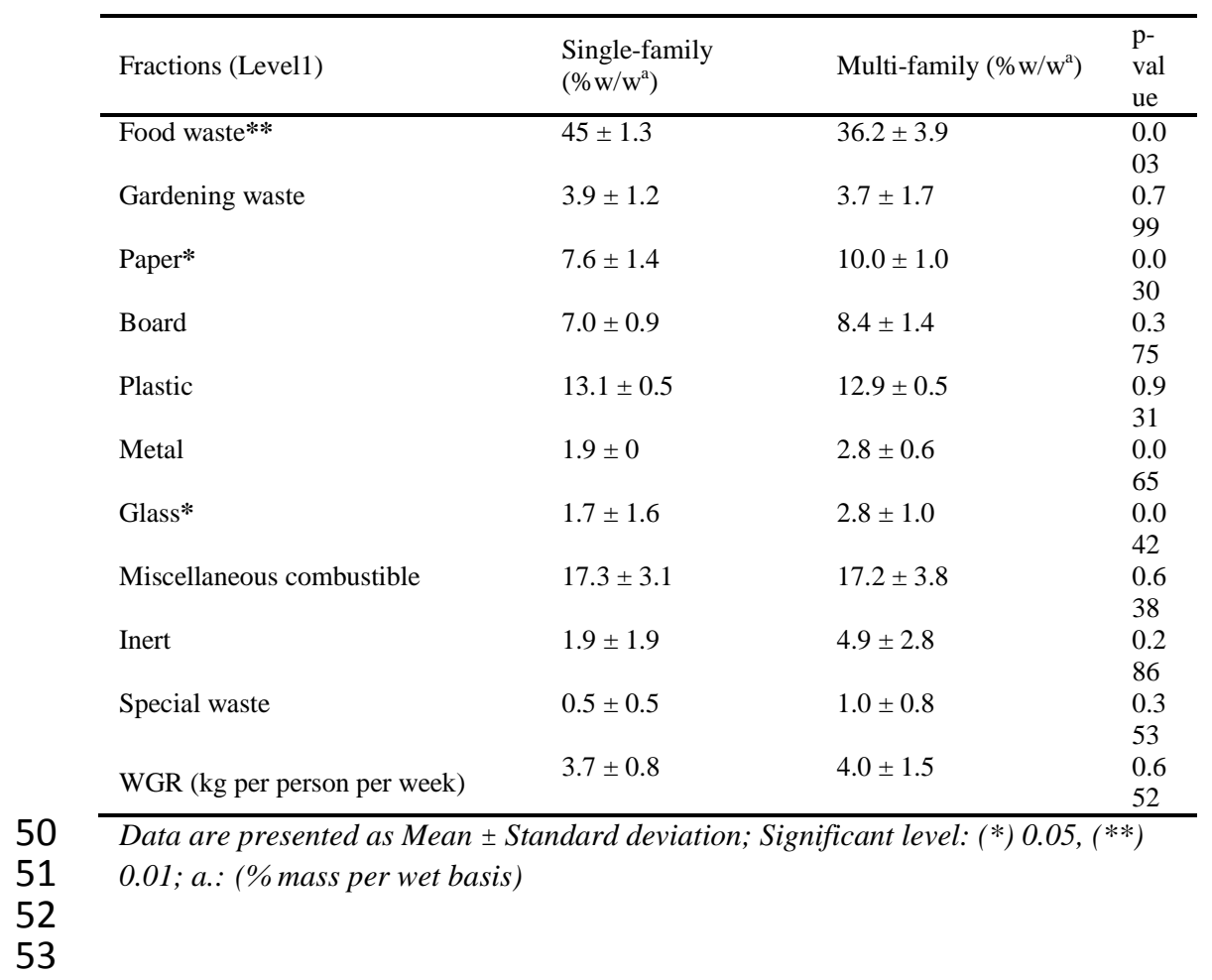


54 Table 9: Waste composition (\% mass per wet basis) based on

55 food packaging sorting procedure and the associated

56 probability values from the permutation test.

\begin{tabular}{llll}
\hline Fractions & Not Included $^{\mathrm{a}}\left(\% \mathrm{w} / \mathrm{w}^{\mathrm{c}}\right)$ & Included $^{\mathrm{b}}\left(\% \mathrm{w} / \mathrm{w}^{\mathrm{c}}\right)$ & P-value \\
\hline Food waste & $45.1 \pm 2.8$ & $42.1 \pm 2.7$ & 0.50 \\
Gardening waste & $4.1 \pm 2.2$ & $4.1 \pm 2.2$ & 1.00 \\
Paper & $8.4 \pm 1.1$ & $8.4 \pm 1.1$ & 1.00 \\
Cardboard & $6.1 \pm 0.4$ & $6.8 \pm 0.4$ & 0.30 \\
Glass & $1.9 \pm 0.3$ & $2.2 \pm 0.3$ & 0.30 \\
Metal & $2.1 \pm 1$ & $2.4 \pm 0.9$ & 0.50 \\
Plastic & $11.5 \pm 1.9$ & $13.2 \pm 2.2$ & 0.60 \\
Miscellaneous combustible & $17.7 \pm 3.3$ & $17.7 \pm 3.3$ & 1.00 \\
Inert & $2.6 \pm 1.5$ & $2.6 \pm 1.5$ & 1.00 \\
Special waste & $0.6 \pm 0.2$ & $0.6 \pm 0.2$ & 1.00 \\
\hline
\end{tabular}

57 Sample size (Number of household) 426; Data are presented as Mean \pm Standard

58 deviation; Significant level: $p<0.05$;

59 a.: food and its packaging were sorted as food waste; b.: food packaging was

60 separated from food; c.: \% mass per wet basis;"

61

62 


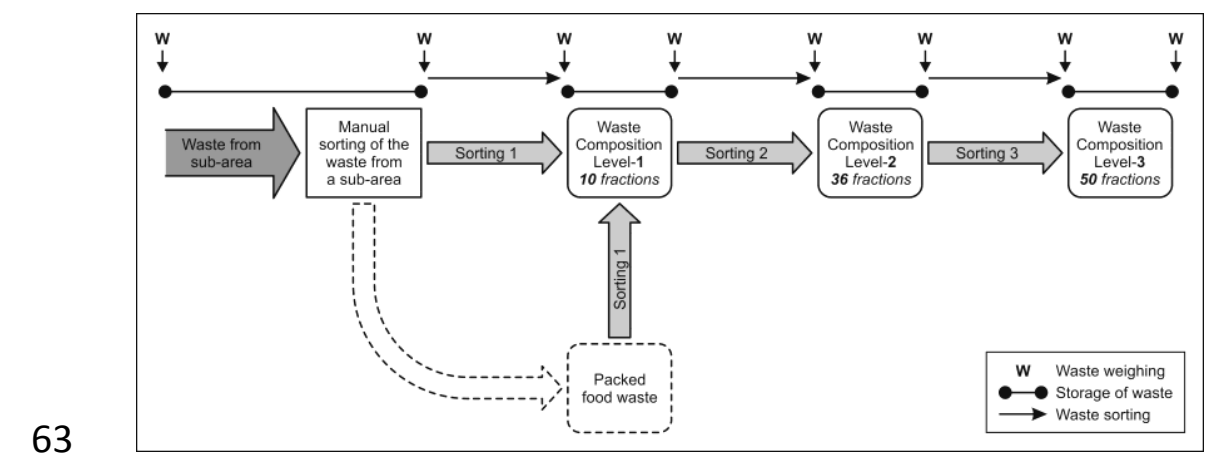

64 Fig. 1. Schema of waste sorting procedure

65
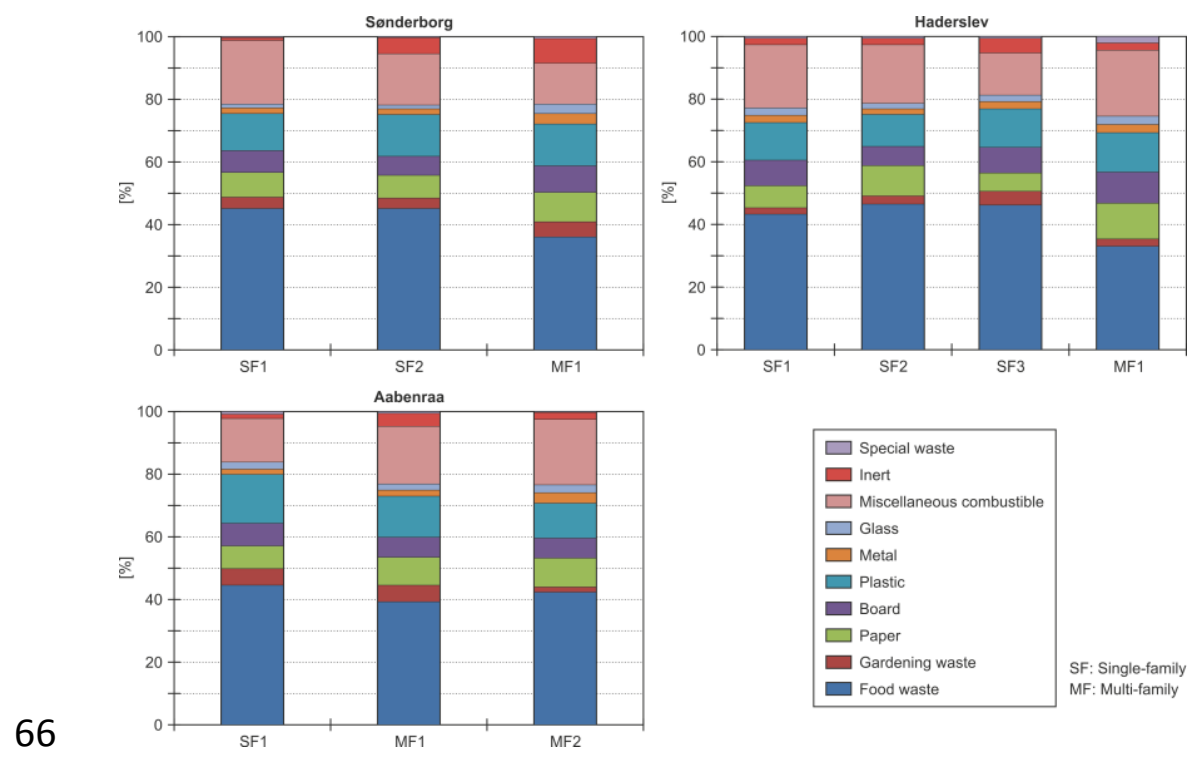

67 Fig. 2. Composition of residual household waste (\% of wet mass) per 68 municipality according to housing types. 


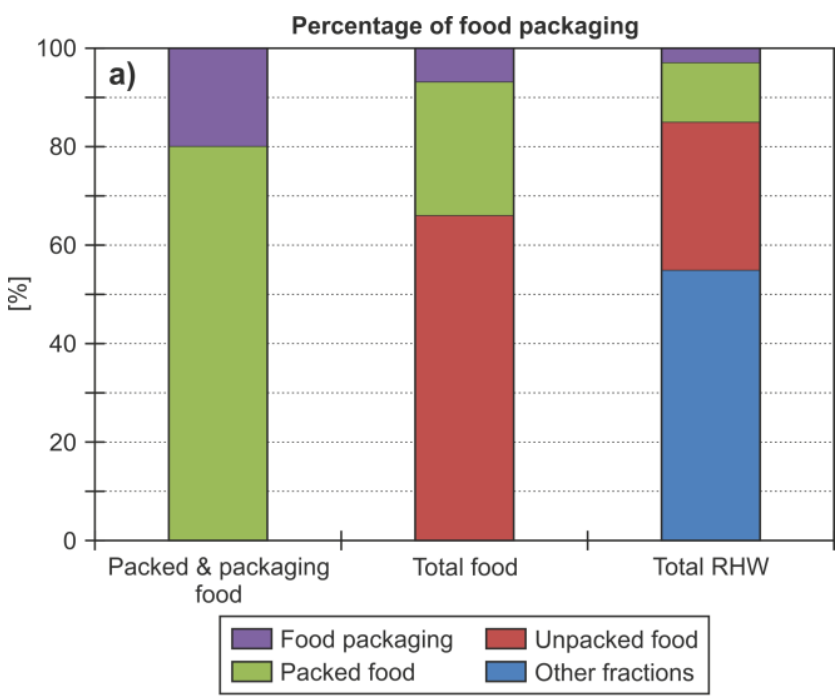

Composition of food packaging

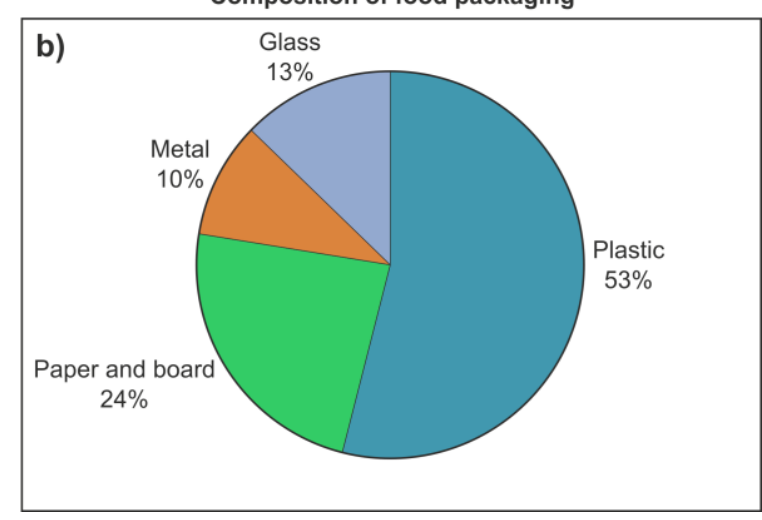

71 Fig. 3. Percentage of food packaging (\% wet mass) in different waste types (a) and composition of packaging (\%wet mass) from food waste (b). 


\section{Supplementary materials}

76 Supplementary material contain background information used

77 for calculation and detailed data from the waste sampling

78 campaign.

79 A: Overall composition of household based on housing type in

80 the study area-Unit is percentage of household

\begin{tabular}{llll}
\hline Municipalities & Housing type & SF $(\%)$ & MF $(\%)$ \\
\hline \multirow{3}{*}{ Sønderborg } & Single- family SF1 & 30 & - \\
& Single-family SF2 & 9 & - \\
& Multi-family MF1 & - & 42 \\
\multirow{5}{*}{ Haderslev } & Single- family SF1 & 11 & - \\
& Single- family SF2 & 11 & - \\
& Single- family SF3 & 5 & 33 \\
Aabenraa & Multi-family MF1 & - & - \\
& Single- family SF1 & 33 & 12 \\
Total & Multi- family MF1 & - & 12 \\
\hline
\end{tabular}

81

Source: Calculated based on data from Statistics Denmark

84 B: Overall composition of household based on housing type

85 and municipalities in the study area-Unit: percentage of

86 households

\begin{tabular}{llll}
\hline Housing type & Sønderborg $(\%)$ & Haderslev $(\%)$ & Aabenraa(\%) \\
\hline Single-family SF1 & 56 & 29 & 80 \\
Single-family SF2 & 17 & 29 & - \\
Single-family SF3 & 0 & 14 & - \\
Multi-family MF1 & 27 & 28 & 10 \\
Multi-family MF2 & 0 & 0 & 10 \\
Total & 100 & 100 & 100 \\
\hline
\end{tabular}

87

Source: Calculated based on data from Statistics Denmark

88

89 

wet basis in $\mathrm{kg}$

\begin{tabular}{|c|c|c|c|c|c|c|c|c|c|c|c|c|c|}
\hline Municipalities & $\begin{array}{l}\text { Dwelling } \\
\text { type }\end{array}$ & $\mathrm{APH}^{\mathrm{a}}$ & $\begin{array}{l}\text { Food } \\
\text { waste }\end{array}$ & $\begin{array}{l}\text { Gardening } \\
\text { waste }\end{array}$ & Paper & Board & Plastic & Metal & Glass & $\mathrm{MC}^{\mathrm{b}}$ & Inert & $\begin{array}{l}\text { Special } \\
\text { waste }\end{array}$ & TotalW \\
\hline Sønderborg & SF1 & 2.3 & 996 & 75 & 177 & 149 & 263 & 41 & 27 & 442 & 23 & 6 & 2,200 \\
\hline Sønderborg & $\mathrm{SF} 2$ & 2.3 & 990 & 77 & 158 & 131 & 295 & 42 & 23 & 361 & 112 & 10 & 2,200 \\
\hline Sønderborg & MF1 & 1.6 & 217 & 29 & 56 & 51 & 80 & 20 & 18 & 79 & 47 & 4 & 600 \\
\hline Harderslev & $\mathrm{SF} 1$ & 2.4 & 950 & 50 & 154 & 177 & 262 & 50 & 53 & 448 & 40 & 15 & 2,200 \\
\hline Harderslev & $\mathrm{SF} 2$ & 2.4 & 792 & 41 & 165 & 106 & 171 & 31 & 32 & 317 & 37 & 8 & 1,700 \\
\hline Harderslev & SF3 & 2.4 & 649 & 61 & 79 & 115 & 174 & 34 & 28 & 186 & 67 & 8 & 1,400 \\
\hline Harderslev & MF1 & 1.6 & 1,088 & 77 & 379 & 324 & 422 & 80 & 95 & 687 & 81 & 67 & 3,300 \\
\hline Aabenraa & SF1 & 2.3 & 668 & 80 & 108 & 109 & 232 & 28 & 31 & 212 & 20 & 11 & 1,500 \\
\hline Aabenraa & MF1 & 1.6 & 236 & 32 & 52 & 40 & 78 & 11 & 12 & 110 & 26 & 3 & 600 \\
\hline Aabenraa & MF2 & 1.6 & 466 & 17 & 102 & 72 & 122 & 37 & 29 & 228 & 23 & 4 & 1,100 \\
\hline
\end{tabular}

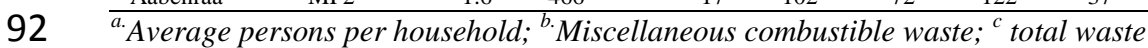

93 sorted;

94

95 D: Summary of the mass loss during waste sorting process

\begin{tabular}{lccc}
\hline Descriptive statistics & Loss $(\%)$ & W1(mass per wet basis in $\mathrm{kg})$ & $\begin{array}{c}\text { W2(mass per wet basis in } \\
\mathrm{kg})\end{array}$ \\
\hline $\mathrm{N}^{*}$ & 76 & 76 & 76 \\
Mean & 1.7 & 16.4 & 16.1 \\
Median & 1.3 & 12.5 & 12.3 \\
$10 \%$ Trimmed Mean & 1.6 & 13.4 & 13.2 \\
1st Quartile & 0.8 & 10.3 & 10.1 \\
3rd Quartile & 2.3 & 17.4 & 17.1 \\
Standard Deviation & 1.1 & 16.9 & 16.6 \\
Interquartile Range & 1.5 & 7.1 & 7.0 \\
Median Absolute & 1.0 & 4.5 & 4.6 \\
Deviation & & & \\
\hline
\end{tabular}

$96 \quad \mathrm{~N}^{*}:$ number of paper sacks;

97 Loss $(\%)$ is mass loss during the waste sorting and storage processes;: Loss=((W1-

$98 \mathrm{~W} 2) / \mathrm{W} 1)^{*} 100$, with W1=net wet mass of waste before sorting, W2: net wet mass of

99 waste after sorting;

100 The average mass loss due to evaporation is $1.7 \%$, which is below $3 \%$. 